Linköping Studies in Science and Technology

Dissertation No. 1954

\title{
Development of soft sensors for monitoring and control of bioprocesses
}

\author{
Robert Gustavsson
}

\section{UNINËDING}

Division of Biotechnology

Department of Physics, Chemistry and Biology

Linköpings universitet, SE-581 83 Linköping, Sweden

Linköping 2018 
(C) Robert Gustavsson, 2018

Printed in Sweden by LiU-Tryck, Linköping, Sweden

ISSN 0345-7524

ISBN 978-91-7685-207-1 


\begin{abstract}
In the manufacture of bio-therapeutics the importance of a wellknown process is key for a high product titer and low batch to batch variations. Soft sensors are based on the concept that online sensor signals can be used as inputs to mathematical models to derive new valuable process information. This information could then be used for better monitoring and control of the bioprocess.

The aim of the present thesis has been to develop soft sensor solutions for upstream bioprocessing and demonstrate their usefulness in improving robustness and increase the batch-to-batch reproducibility in bioprocesses. The thesis reviews the potential and possibilities with soft sensors for use in production of biotherapeutics to realize FDA's process analytical technology (PAT) initiative. Modelling and hardware sensor alternatives which could be used in a soft sensor setup are described and critically analyzed. Different soft sensor approaches to control glucose feeding in fedbatch cultures of Escherichia coli are described. Measurements of metabolic fluxes and specific carbon dioxide production was used as control parameters to increase product yield and decrease the variability of produced recombinant proteins. Metabolic heat signals were used in uninduced cultures to estimate and control the specific growth rate at a desired level and thereby also estimate the biomass concentration online. The introduction of sequential filtering of the signal enabled this method to be used in a down-scaled system. The risk and high impact of contaminations in cell cultures are also described. An in situ microscope (ISM) was used as an online tool to estimate cell concentration and also to determine cell diameter size which enabled the detection of contaminant cells at an early stage.
\end{abstract}

The work presented in this thesis supports the idea that soft sensors can be a useful tool in the strive towards robust and reliable bioprocesses, to ensure high product quality and increased economic profit. 


\section{Populärvetenskaplig sammanfattning}

Principerna för industriell bioteknik har använts av människan under flera tusentals år, långt före kunskapen om mikroorganismer ens var känd. Bröd, fermenterade mejeriprodukter och alkoholhaltiga drycker är exempel på produkter som länge producerats med hjälp av jäst och bakterier. Framsteg inom genteknik har sedan gjort det möjligt att introducera genetisk information i mikroorganismerna och få dem att producera terapeutiska proteiner, exempelvis insulin. Dessa produktionsprocesser ställer extra stora krav på styrningen av processen eftersom det rör sig om levande celler med en inbyggd biologisk variation. Detta kan leda till stora skillnader i både tillväxt och mängd producerad produkt.

Syftet med denna avhandling har varit att demonstrera en metod, soft sensorer, som kan användas för att kombinera den befintliga informationen som fås från processen i matematiska modeller för att estimera nya kritiska parametrar. Dessa kan sedan användas för att styra processen. Genom att använda sig av soft sensorer kan ny viktig kunskap om processen fås fram, vilket ökar möjligheten till en robust och tillförlitlig produktionsprocess.

Avhandlingen ger en överblick över området med en kritisk analys av möjligheterna till att implementera soft sensorer inom läkemedelsprocesser. Tre olika strategier för styrning av en mikrobiell odlingsprocess presenteras $i$ avhandlingen där tillsatsen av substrat till cellerna justeras efter givna parametrar. Den första bygger på att mäta och kontrollera mängden inhiberande restprodukter till en låg nivå som annars kan få negativa konsekvenser för cellernas tillväxt. Den andra strategin bygger på att mäta och kontrollera mängden koldioxid som bildas av cellerna när de tillväxer. Den tredje mäter den metabola värmen som bildas från cellerna när de tillväxer och används för att styra deras tillväxthastighet till en önskad nivå.

Inom läkemedelsproduktion används även kulturer med celler från djur för att producera olika proteiner och antikroppar. Dessa kulturer är dock väldigt känsliga för infektioner av mikroorganismer. I detta arbete demonstreras slutligen en metod, in situ mikroskopi, som i ett 
tidigt skede kan upptäcka en infektion i cellkulturer genom att övervaka cellernas storlek. 


\section{List of publications}

This thesis is based on the following publications:

\section{Paper I}

Carl-Fredrik Mandenius and Robert Gustavsson

Mini-review: soft sensors as means for PAT in the manufacture of bio-therapeutics

Journal of Chemical Technology and Biotechnology, 2015, 90, 215227

Contribution: Critically analyzed the concept and wrote the manuscript together with the co-author.

\section{Paper II}

Robert Gustavsson and Carl-Fredrik Mandenius

Soft sensor control of metabolic fluxes in a recombinant Escherichia coli fed-batch cultivation producing green fluorescence protein

Bioprocess and Biosystems Engineering, 2013, 36, 1375-1384

Contribution: Planned and performed all experiments. Designed the soft sensor and wrote the manuscript together with the co-author. 


\section{Paper III}

Robert Gustavsson, Cornelia Lukasser and Carl-Fredrik Mandenius Control of specific carbon dioxide production in a fed-batch culture producing recombinant protein using a soft sensor

Journal of Biotechnology, 2014, 200, 44-51

Contribution: Planned and performed experiments. Designed the soft sensor and wrote the manuscript together with the co-authors.

\section{Paper IV}

Dan Paulsson, Robert Gustavsson and Carl-Fredrik Mandenius

A soft sensor for bioprocess control based on sequential filtering of metabolic heat signals

Sensors, 2014, 14, 17864-17882

Contribution: Planned and supervised experiments performed by DP. Analyzed data and wrote the manuscript together with the coauthors.

\section{Paper V}

Robert Gustavsson, Carl-Fredrik Mandenius, Sabine Löfgren, Thomas Scheper and Patrick Lindner

In situ microscopy as online tool for detecting microbial contaminations in cell culture

\section{Submitted}

Contribution: Planned and performed all experiments. Designed the soft sensor together with PL and wrote the manuscript with the co-authors. 
Publications not included in this thesis

Carl-Fredrik Mandenius and Robert Gustavsson

Soft Sensor Design for Bioreactor Monitoring and Control

Bioreactors: Design, Operation and Novel Applications, 2016, Chapter 14, Wiley-VCH

Inga Gerlach, Simone Brüning, Robert Gustavsson, Carl-Fredrik Mandenius and Volker C. Hass

Operator training in recombinant protein production using a structured simulator model

Journal of Biotechnology, 2014, 177, 53-59 


\section{Table of Contents}

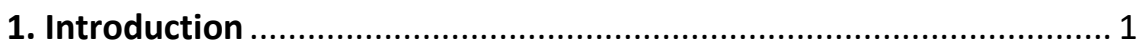

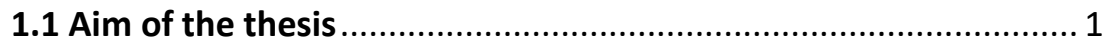

1.2 The concept of soft sensors.......................................................... 2

2. Industrial biotechnology.......................................................... 5

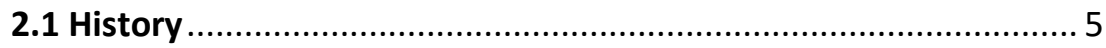

2.2 Recombinant protein production ............................................. 8

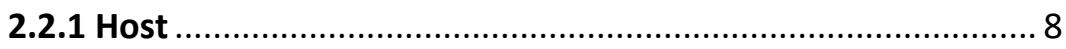

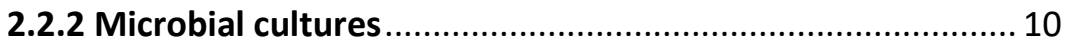

2.2.3 Mammalian cell culture...................................................... 11

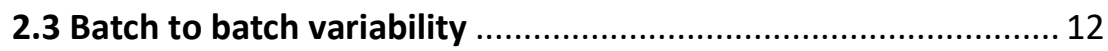

2.4 Process Analytical Technology (PAT) …………....................... 13

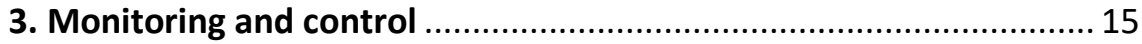

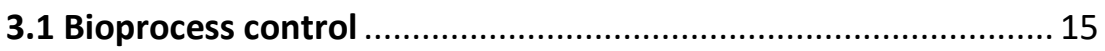

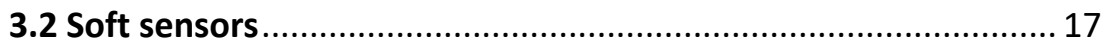

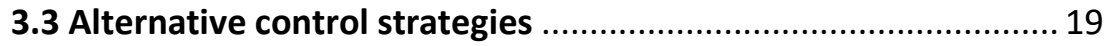

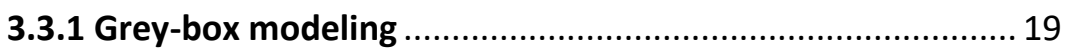

3.3.2 Model predictive control ...................................................... 19

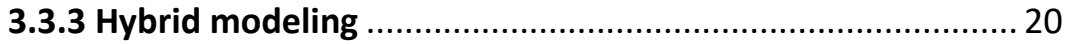

3.4 Data processing and communication ........................................ 21

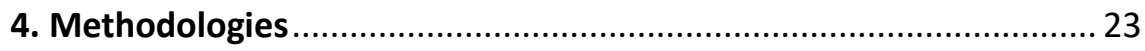

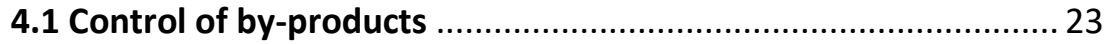

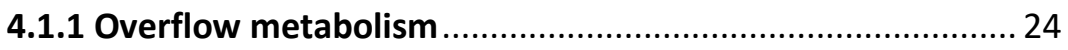

4.1.2 Analytical instruments for monitoring of by-products ........ 24

4.2 Control of carbon dioxide rate ................................................ 26

4.2.1 Carbon dioxide production in microorganisms ................... 26

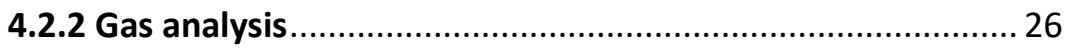


4.3 Control of growth based measurement of metabolic heat ....... 27

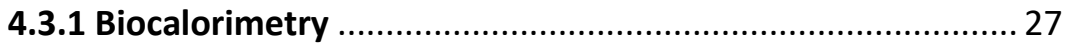

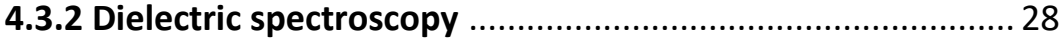

4.4 Detecting contamination in cell culture .............................. 28

4.4.1 In situ microscopy (ISM) ......................................... 29

5. Conclusion and future perspectives ....................................... 31

5.1 Soft sensors ................................................................. 31

5.2 Future perspectives ........................................................ 32

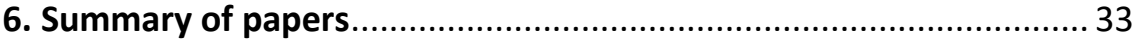

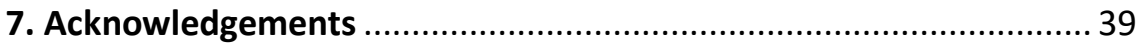

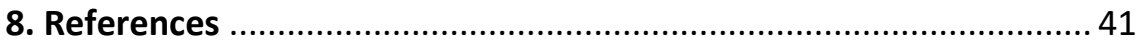




\section{Introduction}

Biotechnology has successfully been used to produce bread, dairy products or alcoholic beverages for thousands of years and in the last century pharmaceuticals can be added to that list [1-3]. By using cells, e.g. microorganisms, as a factory to produce a desired product either by the cells own metabolism or by introducing genetic information into the host cell and produce recombinant proteins. As in any kind of manufacturing industry there is a requirement of knowledge, accurate information and automated feedback control to achieve a robust and reliable production process. The complex nature of a biological system makes this even more complicated and when it comes to pharmaceuticals it places extremely high demands on quality. Automated control of a production process has successfully been used for many years in other related industries such as chemical manufacturing or paper pulp industry $[4,5]$.

\subsection{Aim of the thesis}

The aim of the present thesis has been to develop soft sensor solutions for upstream bioprocessing and demonstrate their usefulness in improving robustness and increase the batch-to-batch reproducibility in bioprocesses.

The first chapter gives a short introduction to the concept of soft sensors and how estimations of parameters can be useful. The development of industrial biotechnology and the challenges included when working with a biological system is described in the second chapter. The third chapter present the use of online monitoring and control of a bioprocess and how these processes can be improved by using soft sensors and other alternative control strategies. In the fourth chapter the methodologies used in the papers are presented and the methods used are described. Concluding remarks based on the thesis and future perspectives are given in chapter five.

This thesis demonstrates the implementation of soft sensors and their ability to improve biotechnical productions processes by improving information about the process and enable automated control. An analysis of how the pharmaceutical production industry could 
benefit from the implementation of soft sensors and their role to reach FDA's process analytical technology ambitions is described in Paper I. Examples of adaption to the current state of the cells with feedback control of by-product metabolites of the cells by controlling the substrate input to increase product yield and lower the variability has been studied in Paper II-III. Using a calorimetric method to estimate and control the specific growth rate of the cells to keep the growth at a desired level was demonstrated in Paper IV. Constructing a method to detect contamination in cell cultures to alert the operator was shown in Paper V. These papers illustrate how biotechnological production processes can be improved by starting with an analysis of a process, followed by examples of feed-back controls of such processes.

\subsection{The concept of soft sensors}

A soft sensor is defined as the combination of hardware sensors and software models to estimate critical parameters [6, 7]. The parameters can be used for a monitoring purpose or as a feedback for automated control. This include estimating new parameters from models by using information given by other parameters. Then why estimate a critical parameter from other signals and not measure the critical parameter directly? One reason could be that advanced and expensive equipment would be required and that a good enough estimate with other cheap and robust sensors is possible, or the simple fact that the critical parameter is not measurable.

An example of this from everyday life that most people encounter is to keep the right speed when driving a car. You get the information of the speed directly on your dashboard, but to actually measure the speed of the car you would need be outside the car and measure the distance travelled divided by a time unit, as in the case at a speed check. The information given to you on the dashboard is actually an estimation of the speed by measuring something else, with the use of electromagnetism. The more modern electronic speedometer operates in a slightly different way than the mechanical variants developed in the early 1900 s but with the same principle of a rotating magnet. The rotation of the cars wheels is used by attaching magnets 
to the cars rotating drive shaft and every time these magnets passes a sensor this is registered, presented in Figure 1. A mathematical model processes the time interval of the pulses from the electronic currents generated from the magnets and estimates a velocity that is displayed on your dashboard.

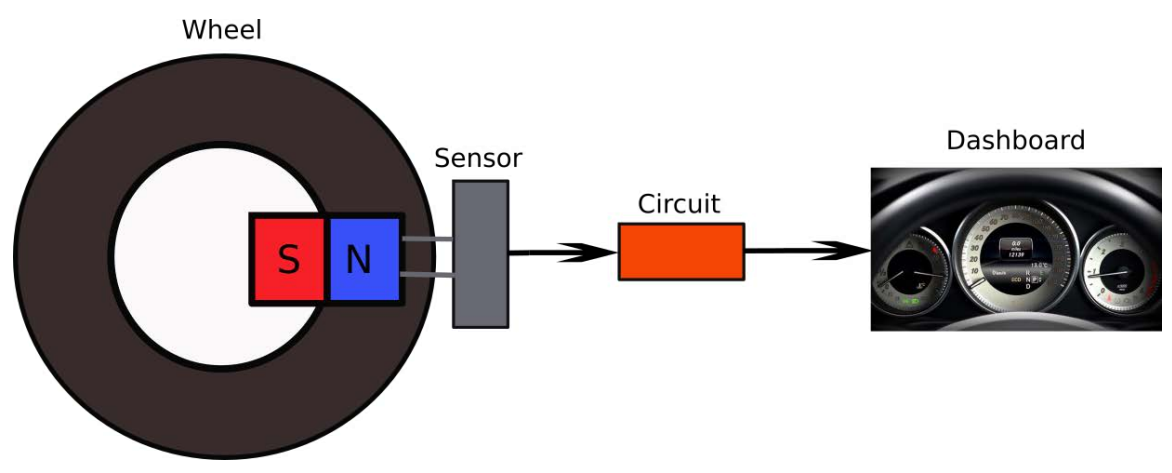

Figure 1 Estimation of velocity in a car. A magnet connected to the driveshaft of a wheel rotates at high speed and triggers a signal each time it passes a connected sensor. A circuit amplifies the signal and translate the signal to an estimated speed on the dashboard.

This will monitor your speed and if you switch on the cruise control an automated control system will use this estimate to adjust the power input to keep the speed at the desired setpoint. Depending on the roads topography or condition, the power input will need to be adjusted to keep a steady speed. A car has the capability to run very fast, much faster than what you ever will drive or set up as desired speed on a cruise control. Except the obvious reason of laws that regulate speed limit, you choose a lower speed because of reasons such as better control to insure safety or lower fuel consumption. Quality of the end product could correspond to you arriving at your destination safe and sound. In modern cars an adaptive cruise control could also adjust the speed depending on the traffic or even brake if any obstacles suddenly appear on the road. This is done with 
advanced models and sensor solutions built in the car, a step towards reliable autonomous vehicles in the future [8].

Many of the same principles could be applied to a bioprocess. When culturing cells in a production process, the rate in which you add nutrients will affect the rate of the growth of the cells which could be compared to the power input and the resulting velocity. A lower specific growth rate than the maximum capacity of the cells is also preferred to insure a controlled process, high quality of end product and high utilization of raw materials. The complex biological system that a cell represents could be resembled to a rout that could include a smooth freeway or just as well a very bumpy road. The power input or the input of substrate then needs to be adjusted depending on current conditions to keep a desired growth rate. However, this is usually not the case in a manufacturing bioprocess. Instead, the input is depending on predicted outcomes and previous results in small scale experiments in the development process. So instead of adapting to current road conditions, a route is predicted without exactly knowing which direction the cells want to take this time. In order to achieve an automated bioprocess, there is a great need to implement sensors and models that would enable a process that adapts to current conditions similar to the example of the automated car. 


\section{Industrial biotechnology}

\subsection{History}

Industrial biotechnology is based on the principle of using metabolic processes in cells or microorganisms to produce a desired product. Biotechnology could be considered a relatively modern field of science. However, the practice of industrial biotechnology is by far the opposite. Even long before the discovery of cells and microorganisms in the seventeenth century by Robert Hooke and Antoni van Leeuwenhoek [9], microorganisms were exploited to preserve food and produce alcoholic beverages with the oldest fermentation known dating back to $7000 \mathrm{BC}$ [2]. The conversion of sugar to alcohol to produce wine and beer as well as production of carbon dioxide to leaven bread, all by the metabolic processes from brewer's yeast, are examples of industrial biotechnology dating back deep in antiquity.

Although successfully used for thousands of years it was first alongside the development of modern light microscopes, leading to the discovery of microorganisms by Hooke and van Leeuwenhoek, when the knowledge of microorganisms could be exploited. In the 1850s Louis Pasteur concluded that fermentation was a living process of yeast and that different types of fermentations was caused by specific microorganisms. Another important contribution by Pasteur towards a more controlled production process was his observation of unwanted bacteria in a fermentation broth which could produce lactic acid and turning the fermentation broth sour. The mild heat treatment which he suggested as a solution to this problem later became known as pasteurization. Fermentation had so far more or less only included food and beverages. However, wars tend to drive technological advancements and during World War I, yeast was used to produce glycerol which was important in ammunition manufacturing.

Another historically important parameter for technological advancements is a bit of luck, which perhaps best is represented by Alexander Fleming and his accidental discovery of penicillin in 1929. His brilliant observation that mold could produce an inhibitory 
agent preventing bacteria to grow in its presence was the starting point of drug development and manufacturing in industrial biotechnology. At first the development of penicillin was slow but eventually accelerated during World War II when many soldiers died from bacterial infections in wounds. After a few years of intense development and improvements, finally in 1943 penicillin could be used to treat soldiers wounded on the battlefield. The discovery and development of penicillin is considered as one of the most important events in the history of medicine [10].

Up until this time, the products manufactured were limited to the natural metabolism of the microorganism of choice and the metabolites it produced. Thanks to the discovery of DNA, its structure and its role of carrying genetic material, this would revolutionize the prospect of producing biopharmaceuticals. A major milestone in the history of DNA was the contribution made by James Watson and Francis Crick with their discovery of the double helix structure of DNA in 1953 [11]. During the 1970s the first few biotechnology companies were established to enable development and large-scale production of biopharmaceuticals. In 1982 the first genetically engineered product to be approved for therapeutic use was recombinant human insulin [3,12]. It was first produced by inserting genes coding for human insulin into the Gram-negative bacterium Escherichia coli (E.coli) and expressed as demonstrated in Figure 2. Chemically synthesized drugs had already been on the market for almost a century. What made the biopharmaceutical drug different was the nature of its structural complexity and size compared to the relatively small chemical drug. This was the start of a long line of approved genetically engineered products e.g. human growth hormone, erythropoietin and Factor VIII [2].

During the same period, monoclonal antibodies (mAbs) were discovered and developed, which is another promising therapeutic protein class [13]. The first mAbs were produced using hybridoma cells, a mouse myeloma cell fused with a white blood cell to create an immortalized cell line able to produce antibodies. Mammalian cells became useful to this class of biopharmaceuticals thanks to their ability to properly fold and glycosylate proteins, a property limited in microorganisms [14]. The following three decades more 
than 150 biopharmaceutical drugs have been approved and with global sales of 228 billion US dollars in 2016, the market and prospect of biopharmaceutical drugs are growing $[15,16]$. Today the biotechnical manufacturing industry covers a wide area of products such as food and beverages [17], pharmaceuticals [18], as well as biofuels $[19,20]$.
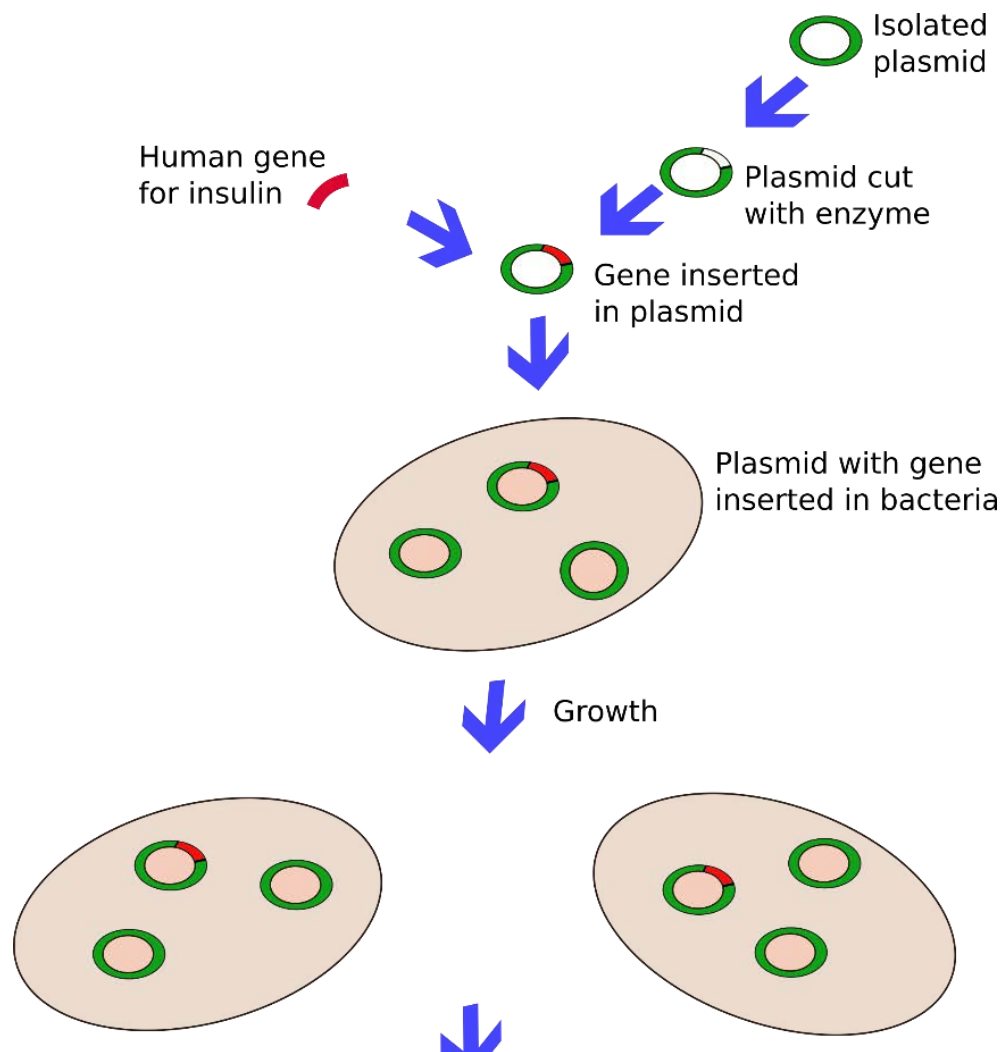

Production of insulin

Figure 2 Expression of recombinant protein by bacteria. Gene coding for human insulin is inserted into a plasmid which is transfected in the host organism. The bacteria are reproduced, and target protein is expressed. 


\subsection{Recombinant protein production}

\subsubsection{Host}

The host cell plays a crucial part since it is the factory producing the desired product. The product could be of the kind that it is naturally produced by the host cell and its metabolism without any genetic modification. However, to improve the productivity of the cell, there could still be modifications done to make it perform better. For recombinant protein production, genetic modification is necessary to make the host cell produce the product. In some cases, the cell could itself be the desired product e.g. bakers' yeast used for baking bread. The choice of host organism depends on several quality attributes of the product. Microorganisms grow fast and give high product yields, however due to their lack of post-translational modifications of proteins they are not suited for all kinds of recombinant proteins. Post-translational modifications are changes to the proteins after their amino acid sequence have been formed in order to fold the protein in its correct active form. In a step closer to the properties of a human eukaryotic cell, mammalian cells offer the advantage of post-translational modifications but have a much lower growth rate and are much more expensive to culture. Different types of organisms are suitable for different kind of purposes. Below is a table that gives an overview of the group of organisms used in recombinant protein production and their properties, Table 1 [21, 22]. Production cost is also a key parameter depending on what kind of product that should be produced. The high production cost and quality demands for a pharmaceutical drug is weighed up by the high value of the product. To have the same production cost to produce the same amount of bioethanol would not be recommended due to the lower value of the end product. 
Table 1 Common organisms used as hosts in industrial production, examples of products and characteristic properties.

Organism

Bacteria

Escherichia coli

Bacillus subtilis

Yeast

Saccharomyces cerevisae Bioethanol

Pichia pastoris

Aspergillus niger

Filamentous fungi

Penicillium chrysogenum
Insulin

Penicillin

Citric acid

\section{Products}

Human growth hormone

Enzymes

Monoclonal antibodies

Recombinant proteins

\section{Characteristic properties}

High growth rates

High yield

Cost effective

No post-translational

modification

High growth rates

High yield

Cost effective

Some post-translational

modification

High yields

Short fermentation time

Eukaryotic post-translational

modification

Post-translational

modifications of proteins

Expensive to grow

Sensitive to contamination 


\subsubsection{Microbial cultures \\ Escherichia coli}

Ever since the first recombinant human insulin, $E$. coli have been one of the most widely used microorganism for producing recombinant therapeutic proteins. The gram-negative bacterium is well studied with its whole genome successfully sequenced [23]. The genetics of $E$. coli is easy to manipulate, and its fast growth and high product yield makes it excellent for production of recombinant proteins [24-28]. The disadvantage is its lack of producing glycosylated proteins and the proteins are often produced as inclusion bodies which require refolding to become active.

Bioreactor fermentations with $E$. coli have been used in Paper II-IV to demonstrate three different soft sensor approaches. E. coli was chosen in these studies due to well-known characteristics, fast growth and its relevance and extensive use in industry today.

\section{Green fluorescence protein (GFP)}

Recombinant protein production in the pharmaceutical industry focuses on proteins for therapeutically use such as insulin or human growth hormone. However, for research purposes the green fluorescence protein (GFP), first isolated from the jellyfish Aequorea victoria in 1962 by Shimomura and co-workers [29], has become widely used and its discovery and development were awarded the Nobel Prize in chemistry in 2008. What has made GFP such a useful protein is its emission maximum at $509 \mathrm{~nm}$, in the lower green portion of visible light, which does not need any cofactors, substrates or additional stabilization to give a detectable signal $[30,31]$. The protein has mostly been used as a reporter gene to enable live cell imaging for transcription and protein localization in cells [32-34]. GFP can also be used as a quantitative reporter of protein concentration since the ratio of fluorescence signal correlates to the protein concentration [35]. Thus, without affecting the cell or adding any kind of cofactor, the product concentration can then be estimated with a quick fluorescence measurement. The fluorescence measurement has the advantage of recording all expressed GFP in the intracellular space without requiring lysis of the E. coli. In situ measurements of fluorescence have been presented [36] and would be another key parameter to monitor online, however no such 
instrument was used in this thesis as off-line samples were taken and analyzed after finished experiment.

GFP was the recombinant protein of choice due to the straightforward and fast measurement of product concentration. In Paper II and III the fluorescence intensity from GFP was used to compare the variability of product concentration between experiments.

\section{Expression system}

To insert the gene that codes for the product of interest into the host, plasmids have traditionally been used as vectors. These small circular double-stranded DNA molecules contains genetic information of the product of interest but could also include control of gene expression or genes for antibiotic resistance for screening of cells that contains the plasmid. The first most commonly used expression system was the lac operon originated from the metabolism of lactose in E. coli [37, 38]. The lac repressor blocks the production of the protein encoded in the lac operon and transcription is initiated first when a co-inducer binds to the repressor. The co-inducer is here represented by the artificial nonmetabolizable allolactose analogue molecule isopropyl- $\beta$-D-1thiogalactopyranoside (IPTG). The expression of the protein of interest can then be controlled during a fermentation depending on when to introduce the inducer molecule.

Plasmid based vectors are still the most popular ones used but also more recent chromosomal based expression systems have been used where the genes are instead integrated in the chromosome of the host $[39,40]$. During long fermentations there is a risk that cells lose their inserted plasmid, a risk that is eliminated using a chromosomal expression system [41].

\subsubsection{Mammalian cell culture}

\section{Monoclonal antibodies}

Monoclonal antibodies ( $\mathrm{mAb}$ ) are increasingly being used for diagnostics and therapeutic purposes. These antibodies are designed to target a specific antigen and can be used in diagnostic kits to test 
immunological responses such as allergic reactions [42]. However, the main use of $\mathrm{mAb}$ today is in specific treatments such as cancer treatments, where it has been the most successful therapeutic during the last two decades [43, 44].

\section{Hybridoma}

Ever since its first use, chinese hamster ovary (CHO) cells have over the years steadily improved the product yield and became the most widely used cell type when it comes to mAb manufacturing [45]. However, the first cell type to be used in the production of mAbs was the mouse hybridoma cell. This cell type is a fusion of a Blymphocyte and one immortal cell from a B-lymphocyte tumor (myeloma cells). The need for this fusion is due to the short lifespan of B-lymphocyte cells when cultured in vitro. The healthy Blymphocyte cell possess the antibody producing ability whilst the immortal myeloma cells contribute with its ability to multiply continually.

Hybridoma cells was used in Paper $\mathbf{V}$ to demonstrate microbial contamination in cell cultures. Hybridoma cells were chosen due to its fast growth and not for the antibody producing capability.

\subsection{Batch to batch variability}

As for any kind of production process, a high batch-to-batch reproducibility is desired to maximize product yield and minimize discarded batches. The product quality is of high importance for the clinical safety and/or efficacy of recombinant biopharmaceuticals. However, the production process of recombinant proteins is dependent on the complexity of the biological system associated with high variability in both cell growth and product titer [46]. An example of high variability in a recombinant protein production process is illustrated in Figure 3. Alterations in the manufacturing process could also have an impact on the quality and properties of a product [47]. This was also highlighted in 2011 when a number of commercially available biopharmaceuticals on the market were tested and discovered to have a variance in product quality between batches [48]. Changes in the biologics manufacturing process are 
tightly regulated by the health authorities. Manufacturers need to demonstrate that the process change does not alter the clinical safety or efficacy of the biologic product. The evaluation of such changes follows a comparability exercise between the pre- and post-change product. Which is focused on the quality level and sometimes, depending on the magnitude of the change and the existing product understanding, also requires comparative data on the preclinical and clinical levels.

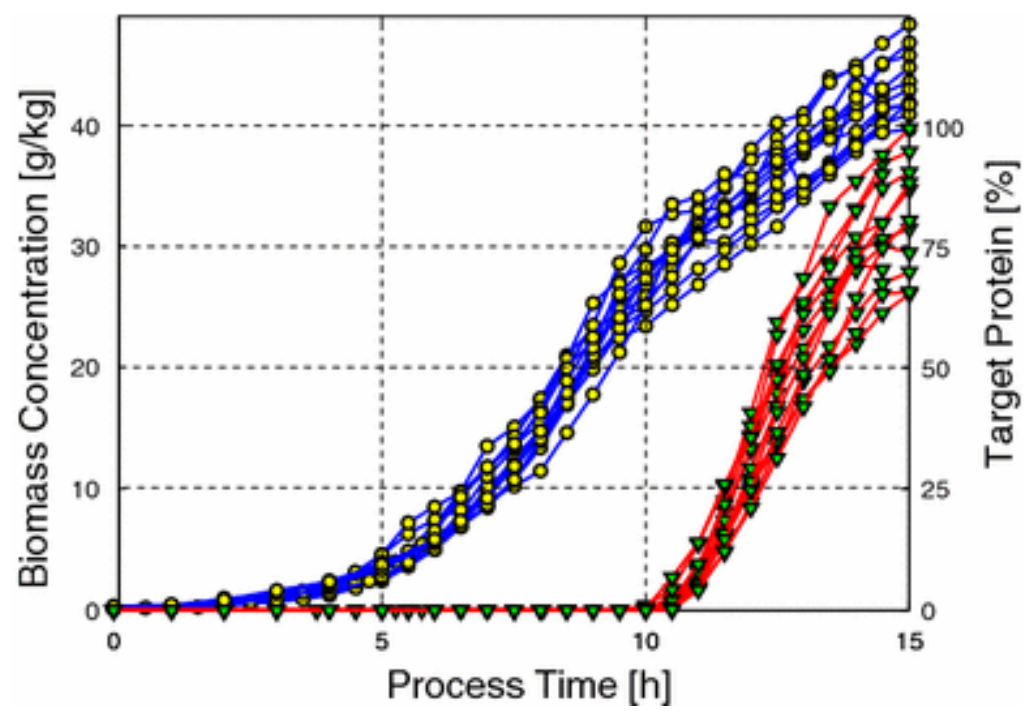

Figure 3 Demonstration of batch to batch variability in biomass concentration (blue) and product titer (red) in a recombinant protein production process [46].

\subsection{Process Analytical Technology (PAT)}

In 2004 the U.S. Food and Drug Administration (FDA) published a guidance for the pharmaceutical industry on process analytical technology (PAT), an initiative to make pharmaceutical manufacturing processes more reliable and efficient [49]. Quality have always been of high importance when it comes to pharmaceuticals. Laboratory testing conducted throughout the whole process, from the start with raw materials to the end product, have 
been the conventional way to accomplish this. The process is usually performed using batch processing with online sensors for key parameters such as $\mathrm{pH}$ and temperature available and with most quality measurements done offline with samples taken and analyzed in the laboratory. PAT aims to build the quality into the manufacturing process by design, measure and control critical process quality attributes (CQA) and critical performance parameters (CPP). In the design phase of the process it is necessary to identify and understand these attributes before moving forward to the analyze phase where suitable analyzers of CQA and CPP are evaluated. The requirement for real-time measurements and onlinesensors is here more extensive compared to the conventional manufacturing process. The aim should then be to use the process understanding to control the process making real-time process decisions keeping process variability low to achieve high and consistent product quality. This aims to result in a more robust process preventing discarded batches, reducing production cycling time and enable continues processing [50].

Quality by design (QbD), to build quality into the process and the importance of process understanding, is well-established in the pharmaceutical industry and PAT is a valuable tool for implementing this $[51,52]$. PAT is addressed by the FDA to all the pharmaceutical industry but could be very beneficial especially to the biopharmaceutical production due to the complex nature and high variability of the biological system [53-55].

Paper I demonstrate and discuss how soft sensors could be used to achieve PAT in the manufacture of biopharmaceuticals. 


\section{Monitoring and control}

\subsection{Bioprocess control}

In a bioprocess, a near optimal environment is key for the cell culture to grow and produce the desired product as efficiently as possible. Bioprocess automation has gone through a significant development since the first pharmaceutical processes were set up where the only automated control was a feedback loop for temperature and where process monitoring was not more advanced than in the beer brewing industry [56]. Techniques and process control tools originally developed in the chemical process industry have successfully been adopted and used in the bioprocess industry. To maintain optimal conditions for the cells and to avoid contamination by other microorganisms the functions and capabilities of the sterilizable culture vessel, a bioreactor, is the essential tool for this purpose. The volume of the bioreactor ranges from small laboratory scale bioreactors with a few liters and all the way up to industrial process bioreactors of several thousands of liters. The bioreactors geometry and instrumentation are usually the same, regardless the size of the vessel, to monitor and control key parameters as demonstrated in Figure 4.

As for the first automated bioprocesses the temperature control of the bioreactor is still one of the key parameters and ensures an optimal temperature suited for the production cell line of the process. In modern bioreactors additional operating variables are controlled even in a standard instrumentation setup, such as $\mathrm{pH}$, pressure, level and dissolved oxygen [57]. The $\mathrm{pH}$ in the culture will change during metabolic activity of the cells and the $\mathrm{pH}$ is controlled within the cells optimal range either by titration of acid and base or with carbon dioxide when it comes to cell cultures. Pressure is of course measured and controlled to avoid accidents caused by an overpressure in the system, but also used to modulate properties of gases and liquids such as boiling point. In order not to exceed the volume of the tank the level is measured and used to control excessive foaming. In an aerobic culture keeping oxygen at a sufficiently high level for the cells is done by measuring the oxygen 
levels in the culture broth, dissolved oxygen (DO). DO is controlled either by increasing aeration or by increasing stirrer speed causing more turbulence and mixing of the culture.

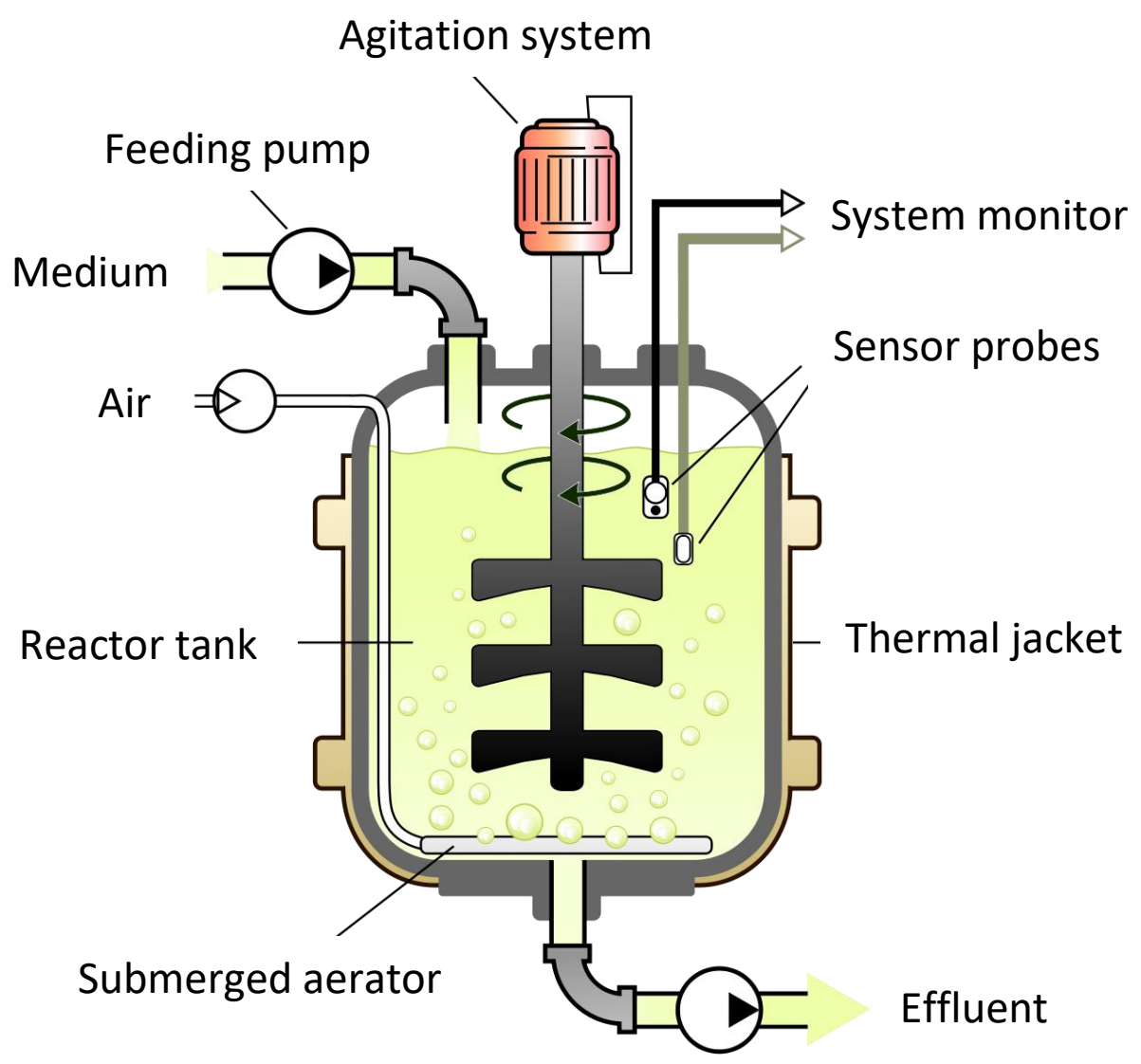

Figure 4 General structure of a stirred-tank bioreactor used in manufacturing processes. Measurements and control of agitation, aeration, temperature and $\mathrm{pH}$ is implemented to maintain optimal conditions for the cells. 
In addition to the standard instrumentation other measuring techniques such as chromatography, spectroscopy and calorimetry can be used to estimate concentration of substrates, metabolites, biomass or product. In the industrial process, these measurements are usually only used for monitoring and to get more information about the state of the process. The possibility to include all this information for an improved and automated process control is considered a key to achieve a more robust and reliable manufacturing bioprocess $[7,53,58,59]$.

\subsection{Soft sensors}

A soft sensor is based on the concept that online sensors can be used as inputs to algorithms that use mathematical models, computation methods and previous knowledge to derive new process information. The concept is commonly referred to as soft sensors, but sometimes also to software sensor, hybrid sensors or model-based sensors. Today the concept is well established in engineering science and parts of the process industry [6]. It was first introduced in bioengineering in the early 1990s and is well established and successfully been applied in academic research [7,60,61], but has however despite this seldom been applied in industry and large-scale applications. The soft sensor principle, seen in Figure 5, is based on hardware sensors monitoring the bioprocess in real time and which generates online data used in the soft sensor model to estimate process parameters. The estimated process parameter can then be used for monitoring purpose or to be implemented in a feedback control of the bioprocess. Models for base titration [62, 63] and calorimetric models [64] to estimate biomass concentration online are some examples of soft sensor setups presented in Paper I.

More recent examples include the implementation of soft sensors in cell cultures to monitor antibody titer [65] and aggregation of antibodies online [66]. The quality in cell cultures has traditionally been built in the process by knowledge from previous testing, but there is a great potential for improvement if the quality instead is built in the process by control [67]. Estimation of glucose concentration have also been reported using a soft sensor based on 
dielectric spectroscopy to monitor biomass growth online [68]. Experiments can be very costly and time-consuming, especially if applied in an industrial scale. This makes in-silico experiments, i.e. computer simulations, very useful and the performance of soft sensors can be tested and evaluated [69, 70]. Improvements of soft sensors have been demonstrated with adaptive models dealing with low data sets and an ability to learn [71]. Soft sensors have a great potential if successfully implemented into bioprocesses, they would be particularly useful for enabling continuous manufacturing processes $[72,73]$.

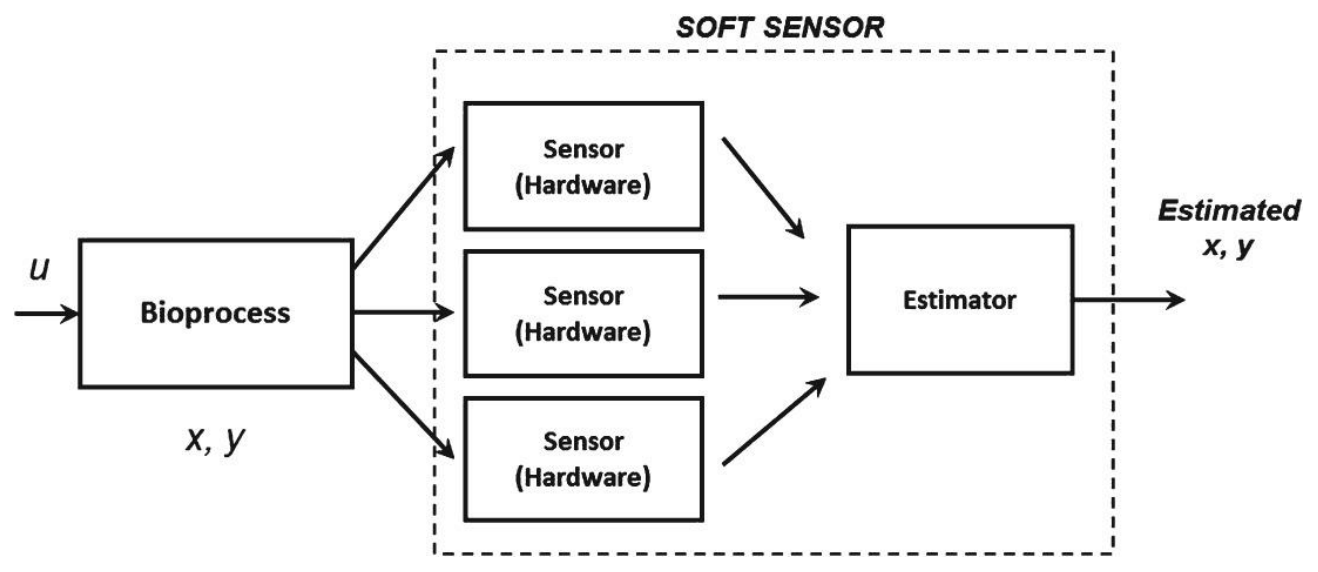

Figure 5 Soft sensor principle where inputs from a bioprocess is measured by hardware sensor/sensors and new information is estimated [74]. 


\subsection{Alternative control strategies}

The benefit with using soft sensors compared to an approach where the state of the processes is predicted by a model, is that soft sensors use the actual state of the process by using online data. This may even require limited knowledge of the process. To accurately predict the process requires a deep knowledge about the process and an advanced mechanistic model that still may show difficulties in handling unforeseen changes in the process. Moreover, there can be applications where soft sensors do not provide estimations that are accurate enough and other models needs to be applied [75].

\subsubsection{Grey-box modeling}

In process modelling a white box model describes the system mathematically based on theoretical mechanistic understanding of the process. In a black box model, the system is mathematically described from observed empirical input and output data, historical or derived online (data-driven modelling). If these modelling approaches are combined, the model is sometimes referred to as a grey box model $[76,77]$, illustrated in Figure 6.

\subsubsection{Model predictive control}

Model predictive control (MPC) is a modelling approach sometimes used in process industry where a dynamic model is combined with online data so that the model makes future predictions about the process and then continuously adjusts the model by comparing previous predictions with online data [78, 79]. MPC has often been applied in the chemical and oil industry whilst bioprocess applications so far are mostly demonstrated in academic laboratories [80]. 


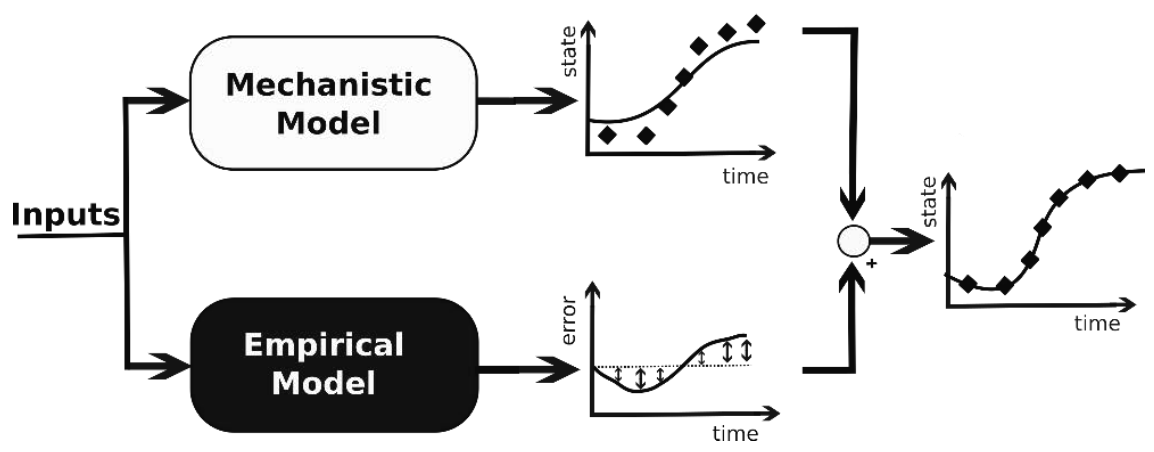

Figure 6 Grey box modeling combining white box model (mechanistic) and black box model (empirical) to create a more accurate model.

\subsubsection{Hybrid modeling}

A similar modelling concept that has gained considerably more attention in the field of bioprocesses is hybrid modeling [81-83]. The traditional bioprocess parametric model is constructed from previous knowledge that is converted into equations and the accuracy of the model is tested and tuned with experiments [84]. A data-driven approach where online measurements are used can be classified as a non-parametric model. One common description of hybrid modeling is the combination of these two approaches which creates a hybrid model where the fundamental model is adjusted by a data-driven model. The description of hybrid modeling may however vary as the term also is used to describe the combination of fundamental models without the influence of online data $[85,86]$.

The potential of hybrid modeling in the bioprocess industry was highlighted already in the 1990s [87] but has gained more and more attention as a tool for achieving quality by design (QBD) and process analytical technology (PAT) in the biopharmaceutical industry [88]. 


\subsection{Data processing and communication}

When using sensors of any kind there is a need for signal processing techniques to reduce or enhance certain aspects of the signal. Digital filters can be used to reduce noise and to get a usable signal. Filtration approaches used in applications for biocalorimetry includes moving averages or high/lowpass filters [89]. Extensive need for signal processing is demonstrated in Paper IV where digital filters are applied to enable a stable signal. This is a prerequisite for the model to accurately estimate the key parameters and enable a reliable control.

The signal may need digital-to-analog and analog-to-digital conversions so that the data can be transferred from one software to another. In an industrial process the data communication is usually integrated into a commercial process control system that handles all the information generated by the measurement instrumentation in the process. Hence, sensors are usually only replaced when worn out. New sensor techniques are rarely introduced especially if that would require a new validation of the process. In a development phase of a process or in an academic environment there is room to be more flexible in introducing new technologies into a process. Many commercial sensors are standalone equipment and can be connected to a number of applications. The sensor then usually comes with its own software where signal processing and algorithms are implemented. The information given by the software can be useful for monitoring purposes of the process but in order to implement the signals from the sensors into a soft sensor or a hybrid model to achieve an automated control, this information need to be accessible in real-time. Open Platform Communications (OPC) is a technology used for easily exchange information between platforms and is widely used in manufacturing industry [90]. Paper $\mathbf{V}$ demonstrates online data communication between software's and the possible use of OPC to integrate sensors for automated control. Implementation of soft sensors could benefit from the development towards digitalization with wireless data transfer and connections to the web $[91,92]$. 


\section{Methodologies}

This thesis relies on the capacities of chosen methodologies to provide accurate information about the state of the process. The methods or sensors used needs to be reliable and robust in order to achieve a secure control of the process. This chapter will present the choice of control parameter and the respective methods used in Paper II-V. Each method has pros and cons, where some of them are very useful in a laboratory environment while they are more difficult to implement in an industrial process. The concept of soft sensors is based on the use of hardware sensors and the information they provide. The estimated parameter is the key and not necessary the specific method used. A method can be exchanged for another method that provides accurate estimation of the same parameter. Factors that determine the choice of method is its ability to be implemented in the process, time to generate data, the robustness of the sensor, the cost or simply what currently is available.

\subsection{Control of by-products}

A challenge in achieving high product yield and low variability between batches is the desire to avoid accumulation of by-products. By-product formation is unwanted since substrate then is being consumed in the formation of these, but more importantly, byproducts such as acetate have negative effects on both cellular growth and product formation [93-96].

In Paper II glucose feeding was controlled by measuring byproduct formation, either the accumulated concentration $\left(\mathrm{c}_{\mathrm{M}}\right)$ or the cells specific production rate $\left(\mathrm{q}_{M}\right)$ of the inhibitory by-products. A direct representation of the amount of by-products in the culture is given by the parameter $\mathrm{c}_{\mathrm{M}}$ and a measure of how fast they are produced is given by the parameter $\mathrm{q}_{\mathrm{M}}$. The aim with using $\mathrm{q}_{\mathrm{M}}$ as control parameter was to focus on the dynamics of the culture and in what direction by-products currently was being formed to compensate for the delay in which results were generated. 


\subsubsection{Overflow metabolism}

One of the reasons for acetate formation in E. coli is due to high levels of glucose. This causes a high flux of acetyl-CoA in the metabolic pathway thus overloading the tricarboxylic acid cycle [97]. Mixed acid fermentation is also a metabolic pathway for acetate and other by-products such as lactate, formate and ethanol caused by anaerobic conditions [98]. Oxygen levels in the cultures are most often measured and controlled at desired levels. However, mixed acid fermentation can still be present due to local oxygen tension gradients or insufficient mixing in large scale reactors [99101]. This makes it important to keep glucose concentration at a desired level. One way to accomplish this is by using a fed-batch feeding strategy for recombinant protein production in E. coli. By continuously adding glucose to the process using a pre-determined feed rate corresponding to a specific growth rate should then result in avoiding the formation of by-products. However, the complex biological system makes the behavior of the cells difficult to predict and a low predicted growth rate could also limit the productivity. A fed-batch process is usually initiated with a short batch phase where an abundance of substrate is added to the culture and the specific growth rate cannot be controlled at a desired level before the substrate from this phase is depleted. The batch phase could then result in a high variability in the starting condition of the culture when reaching the start of the feeding phase. So instead of predicting the behavior of the cells it would be desired to adjust the feeding according to the actual condition of the culture. The straightforward strategy to keep glucose levels controlled at a desired level have been used [102] but also indirect by regulating feeding from dissolved oxygen signal [103].

\subsubsection{Analytical instruments for monitoring of by-products}

High pressure liquid chromatography (HPLC) was applied to estimate the concentration of the by-products. To enable estimation of the specific production rate of by-products, online measurement of biomass concentration was necessary and achieved by using near infrared spectroscopy (NIRS). 
High pressure liquid chromatography (HPLC)

HPLC is a proven and solid chromatography method used for separation of chemical compounds by using a liquid mobile phase and a solid stationary phase. The different compounds will move at different speeds through the column (stationary phase) and eluate at different times. There are different types of columns that separate with respect to different properties e.g. size and polarity. The retention time of each chemical compound is detected with a detector of choice, e.g. refractive index (RID) or ultraviolet light (UV). The retention time is specific for each compound and the concentration is determined by the amplitude of the peak.

HPLC was here used to measure concentration of glucose as well as the metabolic by-products mentioned above (acetate, lactate, formate, ethanol). The HPLC can be run by manually injecting samples but here it was connected directly to the process with a filtration membrane probe to continuously provide the system with a new sample. Each chromatogram took 20 minutes to be completed and there was also a short delay in pumping the sample from the reactor and to reach the injection valve of the HPLC. This means when the results generated from the HPLC is presented it represent the state of the process at least 20 minutes ago. This limits the number of occasions to adjust the process during the feed process.

HPLC can deliver results in high resolution, can detect several compounds in each run and is a relatively quick method. The drawback is the cost and the maintenance required. HPLC is widely used in the pharmaceutical industry, however mainly as an analytical instrument for offline samples and rarely implemented in the process. In this thesis, experiments where performed in a laboratory environment where HPLC successfully could be connected directly to the process with filtration probe and provide information of byproduct concentration.

Near infrared spectroscopy (NIRS)

Near infrared spectroscopy is a method used to study interaction of electromagnetic waves and matter in the near infrared region of the spectrum, between 700-2500 nm [104]. NIRS can be used to identify 
cells and a number of other metabolites e.g. glucose in a culture and have been demonstrated to be very useful in monitoring and control in bioprocesses [105-107]. The NIR probe used in this thesis only include one wavelength band so the accuracy only covers a limited range. However, higher precision can be achieved by using a wider spectral range and a multivariate model [108, 109].

\subsection{Control of carbon dioxide rate}

In Paper III, the specific production rate of carbon dioxide ( $\left.\mathrm{q}_{\mathrm{CO} 2}\right)$ was used as control parameter to adjust the feed rate of substrate. Gas analysis and estimations of $\mathrm{CO}_{2}$ was combined with biomass concentration estimation with NIR-probe. Unlike the HPLC method, which provides a delay in generated results, gas analysis can be performed in real time. This together with a short response time by the NIR probe enables more frequent adjustments of the process controlling according to current conditions.

\subsubsection{Carbon dioxide production in microorganisms}

The relationship between cellular growth of microorganisms and their production of carbon dioxide have been known for a long time [110]. As for all aerobic organisms, carbon dioxide is formed in the tricarboxylic acid cycle when stored energy is used. The respiratory quotient (RQ), the ratio of carbon dioxide production to oxygen consumption, can be used to monitor the efficiency of growth in bacteria and yeast $[111,112]$.

\subsubsection{Gas analysis}

The outlet gas of the bioprocess can give valuable information about the state of the culture by using methods to measure the composition of the gas. Gas analysis of $\mathrm{CO}_{2}$ concentration is standard equipment in most bioprocesses and can be used as an effective tool for process control [113]. The standard method for determining $\mathrm{CO}_{2}$ concentration is measurement of emitted infrared radiation [114]. 


\subsection{Control of growth based measurement of metabolic heat}

In Paper IV, a standard laboratory scale bioreactor was adapted for measurement of metabolic heat produced in a E. coli fermentation with a biocalorimetry-based model adapted from Voisard et al [115]. In previous work with biocalorimetry, high density cultures in large scale volumes are necessary for a stable heat signal. This makes development and testing of biocalorimetry based control strategies in a down-scaled system challenging, which motivates improvements of the method in smaller scale [116]. In this work a laboratory scale reactor and lower cell density was used to demonstrate its functionality in a smaller scale. The resulting lower and unstable signal made it necessary to implement sequential filtration, a serie of filtration methods, for increased robustness. This method requires an advanced model but otherwise simple cheap temperature sensors that are usually already implemented in a process. The drawback is that rapid dynamic changes or varying temperatures in the surroundings can have a negative effect in the stability of the measurement.

The estimation of biomass concentration using a biocalorimetry approach was compared to a capacitance sensor estimating biomass concentration using radio-frequency impedance (RFI).

\subsubsection{Biocalorimetry}

Calorimetry is a method for measuring heat transfer associated with changes in state variables and in a biological process this is referred to as biocalorimetry. The metabolism from most internal cell processes produces heat that is transferred to the culture broth and cooling is necessary. This applies for bacterial or yeast cells with fast cell growth and not as much for mammalian cell cultures with a much lower growth rate. All the heat flows must be accounted for a correct estimation of the heat generated from the cells. Stirring in the reactor, aeration, heat from the environment are a few of all the parameters that effects the heat transfer of the system. The estimated metabolic heat from the cells can then be used for estimation and control of the specific growth rate of the cells [89, 115, 117]. An advantage with a biocalorimetry approach is that only standard 
equipment for measuring and controlling temperature is needed and no extra expensive equipment is necessary [116].

\subsubsection{Dielectric spectroscopy}

Radio-frequency impedance (RFI) is a method for measuring viable cell concentration online in a culture. Under the influence of an electric field a charge separation across the cell membrane occurs and due to the nonconducting nature of the cell membrane, charges will build up inside the cells. The cells will then act as capacitors and the resulting capacitance is proportional to the number of cells. Unlike optical measurement methods, only viable cells with an intact cell membrane will be measured. A capacitance probe that uses radio-frequency impedance can then be used as an online tool to monitor viable cell concentration in a process $[118,119]$. The technology has previously been used primarily on cell cultures and yeast cultures due to an increased ability to provide a strong signal with increased cell size. The sensor was here chosen to evaluate its performance to monitor biomass concentration in a bacterial culture, an application also used by other authors in recent published work [68].

\subsection{Detecting contamination in cell culture}

The risk of contamination in cell cultures is a concern in both small scale laboratory environments as well as in larger cell culture production processes in the pharmaceutical industry $[120,121]$. In Paper V, in situ microscopy (ISM) was used as an online tool to detect contamination in a cell culture by identifying cells based on their cell size. In a customer made software, the results were presented in real time and alerts were triggered if a contamination was detected. 


\subsubsection{In situ microscopy (ISM)}

ISM is a method developed to monitor cells in a cell cultivation or a fermentation [122]. The instrument consists of a metal tube placed inside the bioreactor and with a sampling zone where culture media can flow through, lower segment presented in Figure 7. Inside the tube an objective connected to a CCD-camera is placed to set focus and create images of the cells passing the measurement zone. A software for image analysis is then used to identify the number of cells in each image and estimate their size. Because of the size difference between mammalian and microbial cells, the software could distinguish the cell types and alert if microbial cells where present in the culture. Some different applications where ISM have been used includes cell cultures [123], bacterial fermentation [124], fibroblast cultivation with microcarriers [125] and enzymatic hydrolysis of cellulose [126].

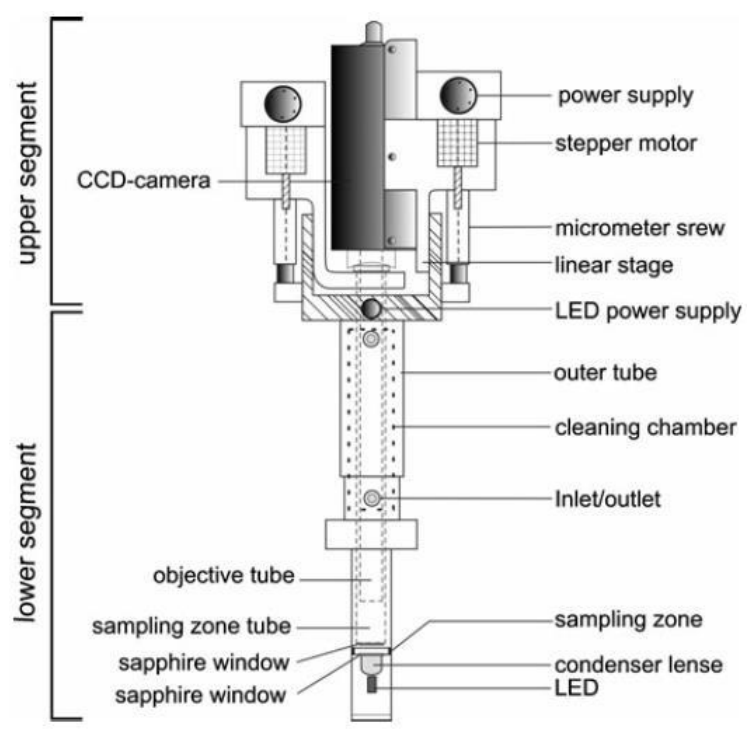

Figure 7 Layout of the in situ microscope used. Lower segment consists of a metal tube connected to the bioreactor via ingold port. Upper segment consists of CCD-camera with an objective tube inserted in the lower segment [122]. 


\section{Conclusion and future perspectives}

More knowledge and accurate information about a process increases the possibility for implementing a robust automated control of the process. The aim is to strive towards a reliable production process with low batch to batch variations, high utilization of resources and a high product quality. The quality should be designed and built into the production process.

\subsection{Soft sensors}

One powerful tool to achieve this is soft sensors that use online signals from the process to derive new information. New implementation of sensors and measuring techniques could be very useful, but the soft sensor should preferably utilize robust sensors already implemented in the process. Soft sensors are not limited to use a few dedicated hardware sensors but can use different sensors that are best suited for the process to deliver estimates of key parameters. Paper I highlights the possibilities and challenges with implementing soft sensors in the bioprocess manufacturing industry.

The soft sensor approaches described in Paper II-III demonstrate how implementations of these control strategies can improve and increase the reproducibility in a production process of recombinant protein. The likelihood that one of these described control strategies would be implemented in a manufacturing process is unlikely. However, the soft sensors described could be considered an option to implement as part in an automated control model with sensors suited for the specific process.

The usefulness of implementing a biocalorimetry based control method to a bioprocess due to the simple and cheap sensors required, makes it an appealing soft sensor tool. Paper IV demonstrates the challenges with working with this method in a down-scaled process and how implementation of sequential filters can be useful in order to make this feasible.

The ability to detect contaminations in cell cultures at an early stage could save time, money or even enable early actions to save the 
culture. The usefulness of in situ microscopy for this purpose, demonstrated in Paper $\mathbf{V}$, would enable an online monitoring technique to detect cell culture contaminations.

This thesis demonstrates the usefulness of soft sensors by implementing control strategies with already existing hardware sensors to improve a production process. Critical process and quality parameters can be estimated and used in decision making or automated control. Also, by introducing new innovative technologies, such as the ISM, the knowledge and information given by these sensors could be beneficial. This makes development in new sensor technologies also an important scientific field that could improve online monitoring.

\subsection{Future perspectives}

This thesis has focused on soft sensors in the upstream part of the bioprocess while the prospects of implementing soft sensors in downstream processing are equally relevant [127]. The upstream process is usually run in batches while the downstream process is a continuous process. There are many economic factors that suggest that a continuous production process in both upstream and downstream would be beneficial $[128,129]$. In order to achieve a continuous production process the requirements of online measurements of quality parameters and control of the process are increased. Soft sensors have the capability to be one of the tools to make continuous biomanufacturing a reality. 


\section{Summary of papers}

\section{Paper I}

Carl-Fredrik Mandenius and Robert Gustavsson

Mini-review: soft sensors as means for PAT in the manufacture of bio-therapeutics

Journal of Chemical Technology and Biotechnology, 2015, 90, 215227

Paper I review the potential and possibilities with soft sensors for use in production of bio-therapeutics to realize FDA's process analytical technology (PAT) initiative. This minireview include a critical analysis of the soft sensor concept from user perspectives, to identify the possibilities and shortcomings in a structural manner where issues such as sensitivity, price and other factors are compared for ranking the sensor options. By identifying the best choice of sensor combinations towards user needs the most realistic alternatives for soft sensor users are screened out. Modelling and hardware sensor alternatives which could be used in a soft sensor setup and examples of implemented soft sensor solutions are described.

By including this analysis, Paper I should not only review the concept of soft sensors but also serve as a catapult for ensuring papers included in this thesis follow at least some of the guidelines in the minireview. 


\section{Paper II}

Robert Gustavsson and Carl-Fredrik Mandenius

Soft sensor control of metabolic fluxes in a recombinant Escherichia coli fed-batch cultivation producing green fluorescence protein

Bioprocess and Biosystems Engineering, 2013, 36, 1375-1384

The aim of Paper II was to improve the robustness and variability in a recombinant protein production process using a soft sensor with the by-product metabolites as control parameter. An HPLC was connected to the bioreactor with the use of filtration probe so that estimated concentrations of organic metabolites could be generated every $20 \mathrm{~min}$ and used to control the feed rate of added substrate. The specific production rate $\left(\mathrm{q}_{\mathrm{M}}\right)$ as well as the accumulated concentration $\left(\mathrm{c}_{\mathrm{M}}\right)$ of organic metabolites was used as control parameter. The specific production rate should reflect the current state of the cells, however the accumulated concentration of byproducts was proven to be a more robust parameter in these experiments. Despite the delay in which results were generated the result suggests that controlling the concentration of by-products at a low level could improve the production process. The process could further be improved by combining both parameters $\mathrm{c}_{\mathrm{M}}$ and $\mathrm{q}_{\mathrm{M}}$ in the model or by using sensors with faster response time. 


\section{Paper III}

Robert Gustavsson, Cornelia Lukasser and Carl-Fredrik Mandenius

Control of specific carbon dioxide production in a fed-batch culture producing recombinant protein using a soft sensor

Journal of Biotechnology, 2014, 200, 44-51

The aim of Paper III was also to improve the robustness and variability in a recombinant protein production process with a soft sensor using the carbon dioxide produced by the cells as control parameter. The gas analysis enables fast data generation and by combining the carbon evolution rate with estimation of biomass concentration, the specific production rate of carbon dioxide $\left(\mathrm{q}_{\mathrm{CO} 2}\right)$ could be estimated and controlled by adjusting the feed rate of added substrate. The change in cell growth caused by induction of the culture motivated an adjustment of the set-point at which the specific production rate was controlled. The soft sensor could improve the process by lower the variability of product compared to reference experiments with no automated control. The process could further be improved by combining the gas analysis which contribute with fast response time with a more robust parameter such as measurements of by-products in Paper II. 


\section{Paper IV}

Dan Paulsson, Robert Gustavsson and Carl-Fredrik Mandenius

\section{A soft sensor for bioprocess control based on sequential filtering of metabolic heat signals}

Sensors, 2014, 14, 17864-17882

The aim of Paper IV was to use existing biocalorimetric models previously used in large scale fermentation and implement these in a lab scale bioreactor to enable scaled down experiments with metabolic heat. The lower heat generated by the scaled down process with lower biomass concentration resulted in a noisy signal which made it necessary to implement sequential filtering of the signals. The metabolic heat model estimated the specific growth rate of the cells and was controlled at a constant growth rate by adjusting the feed rate of substrate. The process was not induced to produce recombinant protein due to the shift in metabolism caused by an induction. However, the soft sensor could successfully estimate and control the specific growth rate to give an accurate estimation of biomass concentration by measuring the metabolic heat generated by the cells. The process was sensitive to rapid dynamic changes of the culture or shifting temperature from the surroundings, but the results suggests that it is possible to implement biocalorimetry in a down scaled system. 


\section{Paper V}

Robert Gustavsson, Carl-Fredrik Mandenius, Sabine Löfgren, Thomas Scheper and Patrick Lindner

\section{In situ microscopy as online tool for detecting microbial contaminations in cell culture}

\section{Submitted}

The aim of Paper $\mathrm{V}$ was to enable online detection of microbial contamination in cell cultures using in situ microscopy (ISM). The risk and high impact of contamination in cell cultures motivates an online detection method. The ISM is connected directly in the process and creates images of the cells that are analyzed in an image processing software. The software detects the number of cells in each image and estimate their properties e.g. cell size. An alert system was constructed were cell size was used as parameter to distinguish cultured cells from cells contaminating the culture. Cultures of hybridoma cells were contaminated with Candida utilis or Pichia stipitis. The low set of data could not give an accurate estimation of cell concentration but was successful in identify when the culture was contaminated and alert the operator. The results suggest that using a method, such as the ISM, that can detect the size of the cells enables an online detection method of contamination in cell cultures. Paper V gives an example of possible soft sensor implementation to handle a problem that is highly relevant to especially cell cultures. 


\section{Acknowledgements}

To my supervisor Carl-Fredrik Mandenius for giving me the opportunity to complete this thesis combined with my employment as a research engineer. Almost 8 years ago you convinced me to take one of your Master thesis projects which turned out to be the start of this $\mathrm{PhD}$ thesis.

My co-supervisor Johan Hyllner for all the discussions and trips to London, it has been a delight at every visit.

Past and present members of The Division of Biotechnology: Maria Thörnqvist for supervising my Master thesis and always being helpful when I came knocking on your door. Gunnar Bergström for being a good co-worker and companion at gala dinners. Jonas Christoffersson, from fulvin to advanced cell cultures, I had a great time working with you and I am very grateful for all your help. Patricia Roch for your graphical skills superior to mine and for helping me when I needed it most. Judit Randek for being cheerful and friendly even if problematic equipment tends to make it difficult for experiments to succeed. Master thesis students Cornelia Lukasser, Dan Paulsson, Jenny Joensuu and Sabine Löfgren whose work forms the basis of some of the articles presented in this thesis. Patrik Ekenberg for software development.

Patrick Lindner and the group of Thomas Scheper for lending us the ISM equipment and enabled an exciting project in the form of the final paper in this thesis.

To all the people around IFM and Linköping University. Special thanks to Hasan Dzuho for helping me repairing an instrument at a crucial moment.

To Kaffeklubben and all the people that joins the traditional 11:30 lunch. Klas, Jörgen, Andrey, Pecca, Dr. Forskgrens fan-club and TBG for all the fun moments outside of work.

To my family whose love and support has always helped me through difficult times in life that made it possible for me to be where I am today. Ellinor for the wonderful person you are and everything you do to bring happiness to my life. 


\section{References}

1. Buchholz, K. and J. Collins, The roots-a short history of industrial microbiology and biotechnology. Applied Microbiology and Biotechnology, 2013. 97(9): p. 3747-3762.

2. Demain, A.L., History of Industrial Biotechnology, in Industrial Biotechnology, W.V. Soetaert, E.J., Editor. 2010, Wiley-VCH: Weinheim. p. 17-77.

3. The, M.J., Human insulin: DNA technology's first drug. Am J Hosp Pharm, 1989. 46: p. 9-11.

4. Hailey, P.A., P. Doherty, P. Tapsell, T. Oliver, and P.K. Aldridge, Automated system for the on-line monitoring of powder blending processes using near-infrared spectroscopy .1. System development and control. Journal of Pharmaceutical and Biomedical Analysis, 1996. 14(5): p. 551-559.

5. Jelali, M., An overview of control performance assessment technology and industrial applications. Control Engineering Practice, 2006. 14(5): p. 441-466.

6. Kadlec, P., B. Gabrys, and S. Strandt, Data-driven Soft Sensors in the process industry. Computers \& Chemical Engineering, 2009. 33(4): p. 795-814.

7. Luttmann, R., D.G. Bracewell, G. Cornelissen, K.V. Gernaey, J. Glassey, V.C. Hass, C. Kaiser, C. Preusse, G. Striedner, and C.F. Mandenius, Soft sensors in bioprocessing: a status report and recommendations. Biotechnol J, 2012. 7(8): p. 1040-8.

8. Magdici, S. and M. Althoff, Adaptive Cruise Control with Safety Guarantees for Autonomous Vehicles. Ifac Papersonline, 2017. 50(1): p. 5774-5781.

9. Gest, H., The discovery of microorganisms by Robert Hooke and Antoni Van Leeuwenhoek, fellows of the Royal Society. Notes and Records of the Royal Society of London, 2004. 58(2): p. 187-201. 
10. Aminov, R.I., A brief history of the antibiotic era: lessons learned and challenges for the future. Frontiers in Microbiology, 2010. 1.

11. Watson, J.D. and F.H.C. Crick, Molecular Structure of Nucleic Acids: A Structure for Deoxyribose Nucleic Acid. Nature, 1953. 171: p. 737.

12. Johnson, I.S., The trials and tribulations of producing the first genetically engineered drug. Nature Reviews Drug Discovery, 2003. 2(9): p. 747-751.

13. Liu, J.K.H., The history of monoclonal antibody development - Progress, remaining challenges and future innovations. Annals of Medicine and Surgery, 2014. 3(4): p. 113-116.

14. Spadiut, O., S. Capone, F. Krainer, A. Glieder, and C. Herwig, Microbials for the production of monoclonal antibodies and antibody fragments. Trends in Biotechnology, 2014. 32(1): p. 54-60.

15. Moorkens, E., N. Meuwissen, I. Huys, P. Declerck, A.G. Vulto, and S. Simoens, The Market of Biopharmaceutical Medicines: A Snapshot of a Diverse Industrial Landscape. Frontiers in Pharmacology, 2017. 8.

16. Ryu, J.K., H.S. Kim, and D.H. Nam, Current status and perspectives of biopharmaceutical drugs. Biotechnology and Bioprocess Engineering, 2012. 17(5): p. 900-911.

17. Maryam, B.M., Datsugwai, M.S.S., Shehu, I. , The role of biotechnology in food production and processing. Industrial engineering, 2017. 1: p. 24-35.

18. Ivanov, K., A. Stoimenova, D. Obreshkova, and L. Saso, Biotechnology in the Production of Pharmaceutical Industry Ingredients: Amino Acids. Biotechnology \& Biotechnological Equipment, 2013. 27(2): p. 3620-3626.

19. Nasir, I.M., T.I.M. Ghazi, and R. Omar, Production of biogas from solid organic wastes through anaerobic digestion: a review. Applied Microbiology and Biotechnology, 2012. 95(2): p. 321-329. 
20. Westman, J.O. and C.J. Franzen, Current progress in high cell density yeast bioprocesses for bioethanol production. Biotechnology Journal, 2015. 10(8): p. 1185-1195.

21. Demain, A.L. and P. Vaishnav, Production of recombinant proteins by microbes and higher organisms. Biotechnology Advances, 2009. 27(3): p. 297-306.

22. Wurm, F.M., Production of recombinant protein therapeutics in cultivated mammalian cells. Nature Biotechnology, 2004. 22(11): p. 1393-1398.

23. Blattner, F.R., G. Plunkett, C.A. Bloch, N.T. Perna, V. Burland, M. Riley, J. ColladoVides, J.D. Glasner, C.K. Rode, G.F. Mayhew, J. Gregor, N.W. Davis, H.A. Kirkpatrick, M.A. Goeden, D.J. Rose, B. Mau, and Y. Shao, The complete genome sequence of Escherichia coli K-12. Science, 1997. 277(5331): p. 1453-\&.

24. Ramirez, D.M. and W.E. Bentley, Characterization of stress and protein turnover from protein overexpression in fedbatch E-coli cultures. Journal of Biotechnology, 1999. 71(13): p. 39-58.

25. Riesenberg, D., V. Schulz, W.A. Knorre, H.D. Pohl, D. Korz, E.A. Sanders, A. Ross, and W.D. Deckwer, High Cell-Density Cultivation of Escherichia-Coli at Controlled Specific GrowthRate. Journal of Biotechnology, 1991. 20(1): p. 17-28.

26. Rosano, G.L. and E.A. Ceccarelli, Recombinant protein expression in Escherichia coli: advances and challenges. Frontiers in Microbiology, 2014. 5.

27. Swartz, J.R., Advances in Escherichia coli production of therapeutic proteins. Current Opinion in Biotechnology, 2001. 12(2): p. 195-201.

28. Toeroek, C., M. Cserjan-Puschmann, K. Bayer, and G. Striedner, Fed-batch like cultivation in a micro-bioreactor: screening conditions relevant for Escherichia coli based production processes. Springerplus, 2015. 4.

29. Shimomura, O., F.H. Johnson, and Y. Saiga, Extraction, Purification and Properties of Aequorin, a Bioluminescent 
Protein from the Luminous Hydromedusan, Aequorea. 1962. 59(3): p. 223-239.

30. Cha, H.J., R. Srivastava, V.M. Vakharia, G. Rao, and W.E. Bentley, Green fluorescent protein as a noninvasive stress probe in resting Escherichia coli cells. Applied and Environmental Microbiology, 1999. 65(2): p. 409-414.

31. Chalfie, M., Y. Tu, G. Euskirchen, W.W. Ward, and D.C. Prasher, Green Fluorescent Protein as a Marker for GeneExpression. Science, 1994. 263(5148): p. 802-805.

32. Cormack, B., Green fluorescent protein as a reporter of transcription and protein localization in fungi. Curr Opin Microbiol, 1998. 1(4): p. 406-10.

33. Pakhomov, A.A. and V.I. Martynov, GFP family: Structural insights into spectral tuning. Chemistry \& Biology, 2008. 15(8): p. 755-764.

34. Phillips, G.J., Green fluorescent protein - a bright idea for the study of bacterial protein localization. Fems Microbiology Letters, 2001. 204(1): p. 9-18.

35. Albano, C.R., L. RandersEichhorn, Q. Chang, W.E. Bentley, and G. Rao, Quantitative measurement of green fluorescent protein expression. Biotechnology Techniques, 1996. 10(12): p. 953-958.

36. Zanzotto, A., P. Boccazzi, N. Gorret, T.K. Van Dyk, A.J. Sinskey, and K.F. Jensen, In situ measurement of bioluminescence and fluorescence in an integrated microbioreactor. Biotechnology and Bioengineering, 2006. 93(1): p. 40-47.

37. Lewis, M., A Tale of Two Repressors. Journal of Molecular Biology, 2011. 409(1): p. 14-27.

38. Marbach, A. and K. Bettenbrock, lac operon induction in Escherichia coli: Systematic comparison of IPTG and TMG induction and influence of the transacetylase LacA. Journal of Biotechnology, 2012. 157(1): p. 82-88.

39. Nakashima, N., H. Akita, and T. Hoshino, Establishment of a novel gene expression method, BICES (biomass-inducible chromosome-based expression system), and its application 
to the production of 2,3-butanediol and acetoin. Metabolic Engineering, 2014. 25: p. 204-214.

40. Youngquist, J.T., R.M. Lennen, D.R. Ranatunga, W.H. Bothfeld, W.D. Marner, and B.F. Pfleger, Kinetic modeling of free fatty acid production in Escherichia coli based on continuous cultivation of a plasmid free strain. Biotechnology and Bioengineering, 2012. 109(6): p. 15181527.

41. Chen, S.Y., M. Larsson, R.C. Robinson, and S.L. Chen, Direct and convenient measurement of plasmid stability in lab and clinical isolates of E. coli (vol 7, 4788, 2017). Scientific Reports, 2018. 8.

42. Siddiqui, M.Z., Monoclonal antibodies as diagnostics; an appraisal. Indian Journal of Pharmaceutical Sciences, 2010. 72(1): p. 12-17.

43. Pento, J.T., Monoclonal Antibodies for the Treatment of Cancer. Anticancer Research, 2017. 37(11): p. 5935-5939.

44. Scott, A.M., J.P. Allison, and J.D. Wolchok, Monoclonal antibodies in cancer therapy. Cancer Immun, 2012. 12.

45. Kunert, R. and D. Reinhart, Advances in recombinant antibody manufacturing. Applied Microbiology and Biotechnology, 2016. 100(8): p. 3451-3461.

46. Jenzsch, M., S. Gnoth, M. Kleinschmidt, R. Simutis, and A. Lubbert, Improving the batch-to-batch reproducibility in microbial cultures during recombinant protein production by guiding the process along a predefined total biomass profile. Bioprocess and Biosystems Engineering, 2006. 29(5-6): p. 315-321.

47. Chirino, A.J. and A. Mire-Sluis, Characterizing biological products and assessing comparability following manufacturing changes. Nature Biotechnology, 2004. 22(11): p. 1383-1391.

48. Schiestl, M., T. Stangler, C. Torella, T. Cepeljnik, H. Toll, and R. Grau, Acceptable changes in quality attributes of glycosylated biopharmaceuticals. Nature Biotechnology, 2011. 29(4): p. 310-312. 
49. FDA, U., Guidance for industry PAT - a framework for innovative pharmaceutical development, manufacturing and quality assurance. 2004.

50. Kornecki, M. and J. Strube, Process Analytical Technology for Advanced Process Control in Biologics Manufacturing with the Aid of Macroscopic Kinetic Modeling.

Bioengineering (Basel), 2018. 5(1).

51. Kamble, R., Sharma, S., Varghese ,V., Mahadik K.R. , Process analytical technology (PAT) in pharmaceutical development and its application. Int J Pharm Sci Rev Res, 2013. 23: p. 212-223.

52. Riley, B.S. and X.H. Li, Quality by Design and Process Analytical Technology for Sterile Products-Where Are We Now? Aaps Pharmscitech, 2011. 12(1): p. 114-118.

53. Carrondo, M.J.T., P.M. Alves, N. Carinhas, J. Glassey, F. Hesse, O.W. Merten, M. Micheletti, T. Noll, R. Oliveira, U. Reichl, A. Staby, A.P. Teixeira, H. Weichert, and C.F. Mandenius, How can measurement, monitoring, modeling and control advance cell culture in industrial biotechnology? Biotechnology Journal, 2012. 7(12): p. 1522-1529.

54. Glassey, J., K.V. Gernaey, C. Clemens, T.W. Schulz, R. Oliveira, G. Striedner, and C.F. Mandenius, Process analytical technology (PAT) for biopharmaceuticals. Biotechnology Journal, 2011. 6(4): p. 369-377.

55. Gnoth, S., M. Jenzsch, R. Simutis, and A. Lubbert, Process Analytical Technology (PAT): Batch-to-batch reproducibility of fermentation processes by robust process operational design and control. Journal of Biotechnology, 2007. 132(2): p. 180-186.

56. Alford, J.S., Bioprocess control: Advances and challenges. Computers \& Chemical Engineering, 2006. 30(10-12): p. 1464-1475.

57. Rodríguez-Duran, L.V., M.T. Torres-Mancera, M.A. TrujilloRoldán, N.A. Valdez-Cruz, E. Favela-Torres, and G. SaucedoCastañeda, 20 - Standard Instruments for Bioprocess Analysis and Control, in Current Developments in 
Biotechnology and Bioengineering, C. Larroche, et al., Editors. 2017, Elsevier. p. 593-626.

58. Johnsson, O., J. Andersson, G. Liden, C. Johnsson, and T. Hagglund, Modelling of the oxygen level response to feed rate perturbations in an industrial scale fermentation process. Process Biochemistry, 2015. 50(4): p. 507-516.

59. Simutis, R. and A. Lubbert, Bioreactor control improves bioprocess performance. Biotechnology Journal, 2015. 10(8): p. 1115-1130.

60. Cheruy, A., Software sensors in bioprocess engineering. Journal of Biotechnology, 1997. 52(3): p. 193-199.

61. Randek, J. and C.F. Mandenius, On-line soft sensing in upstream bioprocessing. Critical Reviews in Biotechnology, 2018. 38(1): p. 106-121.

62. Sundstroem, H. and S.O. Enfors, Software sensors for fermentation processes. Bioprocess and Biosystems Engineering, 2008. 31(2): p. 145-152.

63. Warth, B., G. Rajkai, and C.F. Mandenius, Evaluation of software sensors for on-line estimation of culture conditions in an Escherichia coli cultivation expressing a recombinant protein. Journal of Biotechnology, 2010. 147(1): p. 37-45.

64. Biener, R., A. Steinkamper, and J. Hofmann, Calorimetric control for high cell density cultivation of a recombinant Escherichia coli strain. Journal of Biotechnology, 2010. 146(1-2): p. 45-53.

65. Andre, S., L. Saint Cristau, S. Gaillard, O. Devos, E. Calvosa, and L. Duponchel, In-line and real-time prediction of recombinant antibody titer by in situ Raman spectroscopy. Analytica Chimica Acta, 2015. 892: p. 148-152.

66. Ohadi, K., R.L. Legge, and H.M. Budman, Intrinsic fluorescence-based at situ soft sensor for monitoring monoclonal antibody aggregation. Biotechnology Progress, 2015. 31(5): p. 1423-1432.

67. Sommeregger, W., B. Sissolak, K. Kandra, M. von Stosch, M. Mayer, and G. Striedner, Quality by control: Towards model 
predictive control of mammalian cell culture bioprocesses. Biotechnology Journal, 2017. 12(7).

68. Escalante-Sanchez, A., J. Barrera-Cortes, H.M. PoggiVaraldo, T. Ponce-Noyola, and I.S. Baruch, A soft sensor based on online biomass measurements for the glucose estimation and control of fed-batch cultures of Bacillus thuringiensis. Bioprocess Biosyst Eng, 2018.

69. Golabgir, A., T. Hoch, M. Zhariy, and C. Herwig, Observability Analysis of Biochemical Process Models as a Valuable Tool for the Development of Mechanistic Soft Sensors. Biotechnology Progress, 2015. 31(6): p. 1703-1715.

70. Steinwandter, V., T. Zahel, P. Sagmeister, and C. Herwig, Propagation of measurement accuracy to biomass softsensor estimation and control quality. Analytical and Bioanalytical Chemistry, 2017. 409(3): p. 693-706.

71. Liu, Z.W., Z.Q. Ge, G.J. Chen, and Z.H. Song, Adaptive soft sensors for quality prediction under the framework of Bayesian network. Control Engineering Practice, 2018. 72: p. 19-28.

72. Rato, T.J. and M.S. Reis, Building Optimal Multiresolution Soft Sensors for Continuous Processes. Industrial \& Engineering Chemistry Research, 2018. 57(30): p. 97509765.

73. Rehrl, J., A.P. Karttunen, N. Nicolai, T. Hormann, M. Horn, O. Korhonen, I. Nopens, T. De Beer, and J.G. Khinast, Control of three different continuous pharmaceutical manufacturing processes: Use of soft sensors. International Journal of Pharmaceutics, 2018. 543(1-2): p. 60-72.

74. Mandenius, C.F. and R. Gustavsson, Mini-review: soft sensors as means for PAT in the manufacture of biotherapeutics. Journal of Chemical Technology and Biotechnology, 2015. 90(2): p. 215-227.

75. Ishikawa, N., S. Kim, M. Kano, and S. Hasebe, Root cause analysis of estimation error of a soft-sensor, in Computer Aided Chemical Engineering, M.R. Eden, M.G. Ierapetritou, and G.P. Towler, Editors. 2018, Elsevier. p. 2257-2262. 
76. Khan, M.E., Khan, F., A comparative study of white box, black box and grey box testing techniques. International Journal of Advanced Computer Science and Applications, 2012. 3(6): p. 12-15.

77. Sohlberg, B., Grey box modelling for model predictive control of a heating process. Journal of Process Control, 2003. 13(3): p. 225-238.

78. Hauge, T.A., R. Slora, and B. Lie, Application and roll-out of infinite horizon MPC employing a nonlinear mechanistic model to paper machines. Journal of Process Control, 2005. 15(2): p. 201-213.

79. Isaksson, A.J., J. Sjoberg, D. Tornqvist, L. Ljung, and M. Kok, Using horizon estimation and nonlinear optimization for grey-box identification. Journal of Process Control, 2015. 30: p. 69-79.

80. Yoo, S.J., D.H. Jeong, J.H. Kim, and J.M. Lee, Optimization of microalgal photobioreactor system using model predictive control with experimental validation. Bioprocess and Biosystems Engineering, 2016. 39(8): p. 1235-1246.

81. Laursen, S.O., D. Webb, and W.F. Ramirez, Dynamic hybrid neural network model of an industrial fed-batch fermentation process to produce foreign protein. Computers \& Chemical Engineering, 2007. 31(3): p. 163-170.

82. Simutis, R. and A. Lubbert, Hybrid Approach to State Estimation for Bioprocess Control. Bioengineering (Basel), 2017. 4(1).

83. Teixeira, A., A.E. Cunha, J.J. Clemente, J.L. Moreira, H.J. Cruz, P.M. Alves, M.J.T. Carrondo, and R. Oliveira, Modelling and optimization of a recombinant BHK-21 cultivation process using hybrid grey-box systems. Journal of Biotechnology, 2005. 118(3): p. 290-303.

84. von Stosch, M., R. Oliveira, J. Peres, and S.F. de Azevedo, Hybrid semi-parametric modeling in process systems engineering: Past, present and future. Computers \& Chemical Engineering, 2014. 60: p. 86-101. 
85. Green, P.E., Hybrid Models for Conjoint-Analysis - an Expository Review. Journal of Marketing Research, 1984. 21(2): p. 155-169.

86. Heemels, W.P.M.H., B. De Schutter, and A. Bemporad, Equivalence of hybrid dynamical models. Automatica, 2001. 37(7): p. 1085-1091.

87. Schubert, J., R. Simutis, M. Dors, I. Havlik, and A. Lubbert, Bioprocess Optimization and Control - Application of Hybrid Modeling. Journal of Biotechnology, 1994. 35(1): p. 51-68.

88. von Stosch, M., S. Davy, K. Francois, V. Galvanauskas, J.M. Hamelink, A. Luebbert, M. Mayer, R. Oliveira, R. O'Kennedy, P. Rice, and J. Glassey, Hybrid modeling for quality by design and PAT - benefits and challenges of applications in biopharmaceutical industry. Biotechnology Journal, 2014. 9(6): p. 719-726.

89. Schuler, M.M., S. Sivaprakasam, B. Freeland, A. Hama, K.M. Hughes, and I.W. Marison, Investigation of the potential of biocalorimetry as a process analytical technology (PAT) tool for monitoring and control of Crabtree-negative yeast cultures. Applied Microbiology and Biotechnology, 2012. 93(2): p. 575-584.

90. Cwikla, G., Methods of manufacturing data acquisition for production management - a review. Modern Technologies in Industrial Engineering, 2014. 837: p. 618-623.

91. Mansano, R.K., E.P. Godoy, and A.J.V. Porto, The Benefits of Soft Sensor and Multi-Rate Control for the Implementation of Wireless Networked Control Systems. Sensors, 2014. 14(12): p. 24441-24461.

92. Whitmore, A., A. Agarwal, and L.D. Xu, The Internet of Things-A survey of topics and trends. Information Systems Frontiers, 2015. 17(2): p. 261-274.

93. Han, K., H.C. Lim, and J. Hong, Acetic-Acid Formation in Escherichia-Coli Fermentation. Biotechnology and Bioengineering, 1992. 39(6): p. 663-671.

94. Jensen, E.B. and S. Carlsen, Production of Recombinant Human Growth-Hormone in Escherichia-Coli - Expression of 
Different Precursors and Physiological-Effects of Glucose, Acetate, and Salts. Biotechnology and Bioengineering, 1990. 36(1): p. 1-11.

95. Luli, G.W. and W.R. Strohl, Comparison of Growth, Acetate Production, and Acetate Inhibition of Escherichia-Coli Strains in Batch and Fed-Batch Fermentations. Applied and Environmental Microbiology, 1990. 56(4): p. 1004-1011.

96. Turner, C., M.E. Gregory, and M.K. Turner, A Study of the Effect of Specific Growth-Rate and Acetate on Recombinant Protein-Production of Escherichia-Coli Jm107. Biotechnology Letters, 1994. 16(9): p. 891-896.

97. Eiteman, M.A. and E. Altman, Overcoming acetate in Escherichia coli recombinant protein fermentations. Trends in Biotechnology, 2006. 24(11): p. 530-536.

98. Lara, A.R., C. Vazquez-Limon, G. Gosset, F. Bolivar, A. LopezMunguia, and O.T. Ramirez, Engineering Escherichia coli to improve culture performance and reduce formation of byproducts during recombinant protein production under transient intermittent anaerobic conditions. Biotechnology and Bioengineering, 2006. 94(6): p. 1164-1175.

99. Bylund, F., E. Collet, S.O. Enfors, and G. Larsson, Substrate gradient formation in the large-scale bioreactor lowers cell yield and increases by-product formation. Bioprocess Engineering, 1998. 18(3): p. 171-180.

100. Enfors, S.O., M. Jahic, A. Rozkov, B. Xu, M. Hecker, B. Jurgen, E. Kruger, T. Schweder, G. Hamer, D. O'Beirne, N. Noisommit-Rizzi, M. Reuss, L. Boone, C. Hewitt, C. McFarlane, A. Nienow, T. Kovacs, C. Tragardh, L. Fuchs, J. Revstedt, P.C. Friberg, B. Hjertager, G. Blomsten, H. Skogman, S. Hjort, F. Hoeks, H.Y. Lin, P. Neubauer, R. van der Lans, K. Luyben, P. Vrabel, and A. Manelius, Physiological responses to mixing in large scale bioreactors. Journal of Biotechnology, 2001. 85(2): p. 175-185.

101. Xu, B., M. Jahic, G. Blomsten, and S.O. Enfors, Glucose overflow metabolism and mixed-acid fermentation in aerobic large-scale fed-batch processes with Escherichia 
coli. Applied Microbiology and Biotechnology, 1999. 51(5): p. 564-571.

102. Kleman, G.L., J.J. Chalmers, G.W. Luli, and W.R. Strohl, A Predictive and Feedback-Control Algorithm Maintains a Constant Glucose-Concentration in Fed-Batch

Fermentations. Applied and Environmental Microbiology, 1991. 57(4): p. 910-917.

103. Akesson, M., P. Hagander, and J.P. Axelsson, Avoiding acetate accumulation in Escherichia coli cultures using feedback control of glucose feeding. Biotechnology and Bioengineering, 2001. 73(3): p. 223-230.

104. Scarff, M., S.A. Arnold, L.M. Harvey, and B. McNeil, Near infrared spectroscopy for bioprocess monitoring and control: current status and future trends. Crit Rev Biotechnol, 2006. 26(1): p. 17-39.

105. Goldfeld, M., J. Christensen, D. Pollard, E.R. Gibson, J.T. Olesberg, E.J. Koerperick, K. Lanz, G.W. Small, M.A. Arnold, and C.E. Evans, Advanced near-infrared monitor for stable real-time measurement and control of Pichia pastoris bioprocesses. Biotechnology Progress, 2014. 30(3): p. 749759.

106. Hoehse, M., J. Alves-Rausch, A. Prediger, P. Roch, and C. Grimm, Near-infrared spectroscopy in upstream bioprocesses. Vol. 3. 2015. 153-172.

107. Sandor, M., F. Rüdinger, D. Solle, R. Bienert, C. Grimm, S. Groß, and T. Scheper, NIR-spectroscopy for bioprocess monitoring \& control. BMC Proceedings, 2013. 7(Suppl 6): p. P29-P29.

108. Cervera, A.E., N. Petersen, A.E. Lantz, A. Larsen, and K.V. Gernaey, Application of Near-Infrared Spectroscopy for Monitoring and Control of Cell Culture and Fermentation. Biotechnology Progress, 2009. 25(6): p. 1561-1581.

109. Finn, B., L.M. Harvey, and B. McNeil, Near-infrared spectroscopic monitoring of biomass, glucose, ethanol and protein content in a high cell density baker's yeast fed-batch bioprocess. Yeast, 2006. 23(7): p. 507-517. 
110. Gardner, G.A. and A.W. Carson, Relationship between Carbon Dioxide Production and Growth of Pure Strains of Bacteria on Porcine Muscle. Journal of Applied Bacteriology, 1967. 30(3): p. 500-510.

111. Anderlei, T., W. Zang, M. Papaspyrou, and J. Buchs, Online respiration activity measurement (OTR, CTR, RQ) in shake flasks. Biochemical Engineering Journal, 2004. 17(3): p. 187194.

112. Franzen, C.J., Metabolic flux analysis of RQ-controlled microaerobic ethanol production by Saccharomyces cerevisiae. Yeast, 2003. 20(2): p. 117-132.

113. Valero, F. and J. López-Santín, 22 - Online Analysis for Industrial Bioprocesses: Gas Analysis, in Current Developments in Biotechnology and Bioengineering, C. Larroche, et al., Editors. 2017, Elsevier. p. 649-678.

114. Heinemeyer, O., H. Insam, E.A. Kaiser, and G. Walenzik, Soil microbial biomass and respiration measurements: An automated technique based on infra-red gas analysis. Plant and Soil, 1989. 116(2): p. 191-195.

115. Voisard, D., P. Pugeaud, A.R. Kumar, K. Jenny, K. Jayaraman, I.W. Marison, and U. von Stockar, Development of a largescale biocalorimeter to monitor and control bioprocesses. Biotechnology and Bioengineering, 2002. 80(2): p. 125-138.

116. Schubert, T., U. Breuer, H. Harms, and T. Maskow, Calorimetric bioprocess monitoring by small modifications to a standard bench-scale bioreactor. Journal of Biotechnology, 2007. 130(1): p. 24-31.

117. Biener, R., A. Steinkamper, and T. Horn, Calorimetric control of the specific growth rate during fed-batch cultures of Saccharomyces cerevisiae. Journal of Biotechnology, 2012. 160(3-4): p. 195-201.

118. Carvell, J.P. and J.E. Dowd, On-line measurements and control of viable cell density in cell culture manufacturing processes using radio-frequency impedance. Cytotechnology, 2006. 50(1-3): p. 35-48. 
119. Kaiser, C., J. P. Carvell, and R. Luttmann, A Sensitive, Compact, In Situ Biomass Measurement System Controlling and Monitoring Microbial Fermentations Using RadioFrequency Impedance. Vol. 5. 2006.

120. Baumstummler, A., R. Chollet, H. Meder, C. Rofel, A. Venchiarutti, and S. Ribault, Detection of microbial contaminants in mammalian cell cultures using a new fluorescence-based staining method. Letters in Applied Microbiology, 2010. 51(6): p. 671-677.

121. Bachinger, T., U. Riese, R.K. Eriksson, and C.F. Mandenius, Gas sensor arrays for early detection of infection in mammalian cell culture. Biosensors \& Bioelectronics, 2002. 17(5): p. 395-403.

122. Bluma, A., T. Hopfner, P. Lindner, C. Rehbock, S. Beutel, D. Riechers, B. Hitzmann, and T. Scheper, In-situ imaging sensors for bioprocess monitoring: state of the art. Analytical and Bioanalytical Chemistry, 2010. 398(6): p. 2429-2438.

123. Joeris, K., J.G. Frerichs, K. Konstantinov, and T. Scheper, Insitu microscopy: Online process monitoring of mammalian cell cultures. Cytotechnology, 2002. 38(1-2): p. 129-134.

124. Marquard, D., C. Schneider-Barthold, S. Dusterloh, T. Scheper, and P. Lindner, Online monitoring of cell concentration in high cell density Escherichia coli cultivations using in situ Microscopy. Journal of Biotechnology, 2017. 259: p. 83-85.

125. Rudolph, G., P. Lindner, A. Gierse, A. Bluma, G. Martinez, B. Hitzmann, and T. Scheper, Online monitoring of microcarrier based fibroblast cultivations with in situ microscopy. Biotechnology and Bioengineering, 2008. 99(1): p. 136-145.

126. Opitz, B., A. Prediger, C. Luder, M. Eckstein, L. Hilterhaus, P. Lindner, S. Beutel, T. Scheper, and A. Liese, In Situ Microscopy for In-line Monitoring of the Enzymatic Hydrolysis of Cellulose. Analytical Chemistry, 2013. 85(17): p. 8121-8126. 
127. Roch, P. and C.F. Mandenius, On-line monitoring of downstream bioprocesses. Current Opinion in Chemical Engineering, 2016. 14: p. 112-120.

128. Goudar, C.T., N. Titchener-Hooker, and K. Konstantinov, Integrated continuous biomanufacturing: A new paradigm for biopharmaceutical production. Journal of Biotechnology, 2015. 213: p. 1-2.

129. Walther, J., R. Godawat, C. Hwang, Y. Abe, A. Sinclair, and K. Konstantinov, The business impact of an integrated continuous biomanufacturing platform for recombinant protein production. Journal of Biotechnology, 2015. 213: p. 3-12. 


\section{Articles}

The articles associated with this thesis have been removed for copyright reasons. For more details about these see:

http://urn.kb.se/resolve?urn=urn:nbn:se:liu:diva-152439 